\title{
The Effects of Thermo-mechanical Aging on Microleakage in Composite Restorations Polymerized Using One New Generation and Two Conventional Led Light Curing Units
}

\author{
Termomekanik Yaşlandırma Sonrası Sınıf V Kompozit Restorasyonların \\ Mikrosızıntısı Üzerine Biri Yeni Nesil ikisi Geleneksel LED ışık Cihazlarının Etkisi
}

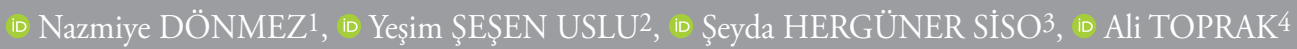

${ }^{1}$ Bezmialem Vakıf University Faculty of Dentistry, Department of Restorative Dentistry, İstanbul, Turkey

2Okan University Faculty of Dentistry, Department of Restorative Dentistry, İstanbul, Turkey

${ }^{3}$ İstanbul Aydın University Faculty of Dentistry, Department of Restorative Dentistry, İstanbul, Turkey

${ }^{4}$ Bezmialem Vakıf University, Department of Biostatistics, İstanbul, Turkey

\section{ABSTRACT}

Objective: This study aimed to evaluate the effects of thermomechanical aging (TMA) on the microleakage scores of Class $\mathrm{V}$ composite restorations polymerized using one new generational and two conventional light emitting diodes (LED) light curing units (LCU).

Methods: Class V cavities were prepared and restored on the buccal and lingual surfaces of 60 extracted human premolar teeth using a dental phantom head to simulate clinical conditions. After application of the adhesive system (Optibond Solo Plus, Kerr, USA) using total etch procedures, the cavities were restored with composite resin (Herculite XRV, Kerr, USA) using one new generational (Demi Ultracapacitor, Kerr, USA) and two conventional (Valo Cordless, USA and BA Optima International, UK) LED light devices. The restored teeth were then subdivided into the test (underwent TMA) and control (did not undergo TMA) groups, and the specimens were stained with $0.5 \%$ basic fuchsin dye and sectioned. Dye penetration was scored using a stereomicroscope at 40x magnification. Differences between groups were compared using the Kruskal-Wallis, Mann-Whitney U, and Wilcoxon Signed Ranks tests $(\mathrm{p}<0.05)$.
ÖZ

\begin{abstract}
Amaç: $\mathrm{Bu}$ çalışmanın amacı termomekanik yaşlandırma (TMY) sonrası Sınıf V kompozit restorasyonların mikrosızıntısı üzerine, biri yeni nesil, ikisi geleneksel olmak üzere ışık yayan diyot (LED) ı̧̧ı cihazlarının etkisini değerlendirmektir.
\end{abstract}

Yöntemler: Altmış adet çekilmiş insan premolar dişi kullanıldı. Sınıf V kaviteler dişlerin bukkal ve lingual yüzeylerine açıldı. Kompozit restorasyonların yapımı LED ışık cihazlarının uzaklığını ağız ortamındaki gibi taklit edebilmek amacıyla bir fantom kafa içerisinde gerçekleştirildi. Adeziv sistem (Optibond Solo Plus, Kerr, ABD) total etch prosedürü ile uygulandıktan sonra kaviteler kompozit rezin (Herculite XRV, Kerr, ABD) ile restore edildi. Polimerizasyon, biri yeni nesil (Demi Ultracapacitor, Kerr, ABD) diğerleri geleneksel olan iki LED ışık cihazı (Valo Cordless, Ultradent, ABD ve BA Optima 10 LED LCU (B.A. International, İngiltere) ile gerçekleştirildi. Daha sonra TMY prosedürüne (yapılan ve yapılmayan) göre dişler 2 alt gruba ayrıldıktan sonra bir gruba TMY uygulandı. Örnekler $\% 0,5$ bazik fuksin ile boyandıktan sonra kesildi. Boya sızıntı skorları x 40 büyütmede stereomikroskop altında incelendi. İstatistiksel analizler Kruskal-Wallis, Mann-Whitney U ve Wilcoxon Signed Ranks testleri kullanılarak yapıldı $(\mathrm{p}<0,05)$.

Address for Correspondence: Nazmiye DÖNMEZ, Bezmialem Vakıf University Faculty of Dentistry, Department of Restorative Dentistry, İstanbul, Turkey

E-mail: nazmiyedonmez@hotmail.com ORCID ID: orcid.org/0000-0002-5101-6155

Cite this article as: Dönmez N, Şeşen Uslu Y, Hergüner Siso Ş, Toprak A. The Effects of Thermomechanical Aging on Microleakage in Composite Restorations Polymerized Using One New Generation and Two Conventional Led Light Curing Units. Bezmialem Science 2021;9(1):91-7. 
Results: Comparison of the test and control groups by the LCUs used for polymerization showed a statistically significant difference in microleakage scores between the two $(\mathrm{p}<0.05)$. However, no differences in scores were observed between the new generational and two conventional LED LCUs ( $p>0.05)$.

Conclusion: Thermal and mechanical aging procedures increased microleakage in Class V composite restorations, regardless of the light curing unit used.

Keywords: Oral simulation, thermo-mechanical aging, LED light curing units, microleakage, class $\mathrm{V}$ cavity
Bulgular: Farklı ışı cihazları ile polimerize edilen deney grupları yaşlandırma prosedürü açısından karşılaştırıldığında, gruplar arasında istatistiksel olarak anlamlı bir fark görüldü $(\mathrm{p}<0,05)$. Mikrosızıntı skorlarına göre yeni nesil ile iki geleneksel LED ışık cihazları arasında arasında fark gözlenmedi $(\mathrm{p}>0,05)$.

Sonuç: Termal ve mekanik yaşlandırma prosedürleri, ışık cihazlarının jenerasyonlarına bakılmaksızın, Sınıf V kompozit restorasyonlarda mikro sızıntıyı artırdı.

Anahtar Sözcükler: Oral simülasyon, termo-mekanik yaşlandırma, LED ışık cihazları, mikro sızıntı, sınıf V kavite

\section{Introduction}

Composite resins are becoming increasingly popular in restorative dentistry due to their aesthetic acceptability. These materials typically do not contain mercury and restorations can be completed with minimal invasive cavity preparation and the use of adhesive bonding systems (1). This increasing demand for composite resins has led to considerable improvements in their physical properties while ensuring adequate polymerization so as to avoid poor bonding to the dental tissues and subsequent microleakage, postoperative sensitivity, discoloration, secondary caries, and irritation of the pulp (2).

The thickness of resin placed in the cavity may influence the degree of polymerization by dispersing the applied light and significantly decreasing its intensity, brightness, and curing action as it descends into the deeper layers (3).

Photo-polymerization of composite resins using blue light was first carried out in the 1970s (4). Since then, almost all commercially available dental composites utilize light curing units (LCUs) based on various physical principles such as quartz-tungsten-halogen (QTH) bulbs, lasers, plasma arc lights, and light emitting diodes (LEDs), with the standard device of choice in modern dental practices being LED LCUs (5). Upon commencement of polymerization, photo-initiator molecules present in the composite resin are activated by a light source in a similar spectrum (1), with conventional LCU and those belonging to newer generations being effective at $<1,000 \mathrm{~mW} /$ $\mathrm{cm}^{2}$ and $\geq 1,000 \mathrm{~mW} / \mathrm{cm}^{2}$ wavelengths, respectively. One of the major advantages of new generation LED LCUs over conventional ones include narrow emission range, effective and rapid photopolymerization (5), overall energy efficiency per cure cycle (5), and prolonged lifetime (6). Nowadays, all commercially available high-powered LED curing devices emit light within the spectrum and power density necessary to ensure sufficient curing of the resin composite $(7,8)$, and some manufacturers have also chosen to increase the power output of these devices in order to achieve an equal degree of curing within a shorter exposure time (7).

Due to unfavorable features, LED LCUs are the most commonly preferred sources. The advantages of LED LCUs include prolonged lamp life, no heat production during usage, no need for filters, a lack of wires, and no changes in light intensity over time (9). However, unlike tungsten lamps which have a wide emission spectrum, these light sources are limited by their monochromatic emission spectrum similar to lasers (10).

The majority of LED light sources have a wavelength of 450-470 $\mathrm{nm}$ and are considered to be powerful despite having a narrow light spectrum as they allow adequate polymerization within shorter irradiation periods (5) and contain photo initiators that can be activated by this wavelength (9).

C.U.R.E (Curing Uniformity and Reduced Energy) Technology is a new generation, wireless, battery-free, LED light curing unit with a patented ultracapacitor light source (11) that generates adequate power to provide uniform cure depth with low heat over a short period of time. While ultra-capacitors resemble conventional batteries with regard to their shape and size, they operate differently by producing re-usable energy within a couple of seconds and maintaining their energy capacity for years. In clinical practice, ultra-capacitors can achieve curing in 25 to 40 seconds (11).

Composite restorations performed in the clinical setting differ considerably from in vitro restorations carried out in a phantom jaw with regard to factors that affect treatment success including level of clinician comfort, risk of saliva contamination, unstable patient head position, pain caused by rotary instruments, and insufficient light and visibility when treating posterior teeth. Moreover, in the oral environment, teeth are continuously subjected to stress and fatigue caused by mastication, swallowing, parafunctional habits and thermal applications (12), and reproduction of these conditions in in vitro settings is necessary for accurate results (13).

The aim of the current study was to investigate the effects of thermo-mechanical aging (TMA) on microleakage in Class $\mathrm{V}$ composite resin restorations polymerized using one new generational and two conventional LED LCUs. The restorations were created on a phantom head using human extracted premolar teeth, and the null hypotheses were that microleakage in Class V composite resin restorations would a) be affected by TMA and b) would decrease upon use of LED LCUs.

\section{Method}

This study utilized 60 freshly extracted human mandibular premolar teeth which were cleaned and polished with scalers to 
remove organic debris. The teeth were examined under a light microscope to allow exclusion of those with cracks, and were then stored in $0.2 \%$ Cloramin $\mathrm{T}$ solution at $4{ }^{\circ} \mathrm{C}$ for one week to prevent bacterial growth.

\section{Cavity Preparation}

The same operator prepared Class V cavities on the buccal and lingual aspects of all teeth, ensuring that the occlusal and gingival margins were located on the enamel and dentin, respectively. No bevels were applied to the teeth, and the cavity dimensions (width $\mathrm{x}$ height $\mathrm{x}$ depth: $3 \times 2 \times 2 \mathrm{~mm}$ ) were controlled using a periodontal probe (Figure 1).

Simulation Model: A mandibular prototype model was created using dental stone, and the right mandibular premolar region was excavated to allow placement of the extracted premolar human teeth using silicon impression material. Thereafter, restorations were performed on the dental phantom head (KDF01 Phantom Unit System for Students-Kemal Dis, Turkey) with the mouth opening (measured between the incisal edges) fixed at $58 \mathrm{~mm}$ in order to simulate application of LED LCUs in the oral environment (Figure 2).

Restoration of the Teeth: The teeth were randomly divided into three groups $(\mathrm{n}=20)$ as per the LCU used. Thereafter, $37 \%$ phosphoric acid (Kerr, USA) was used to etch the enamel margins and dentin structure for 30 and 15 seconds, respectively, and the teeth were then rinsed with water for 40 seconds. The adhesive system (Opti Bond Solo plus, Kerr, USA) was applied in 2 coats as per the manufacturers' instructions using a microbrush, and then polymerized for 5 seconds with the Demi Ultracapacitor (Kerr, USA) or for 10 seconds with the Valo Cordless (Ultradent, USA) and BA Optima 10 LED LCUs (BA International, UK). The composite resin restorations (Herculite XRV Ultra, Kerr, USA) were polymerized with the same LCUs for 20 seconds as per the manufacturers' instructions, and then finished and polished using a multi-step polishing system (Super-

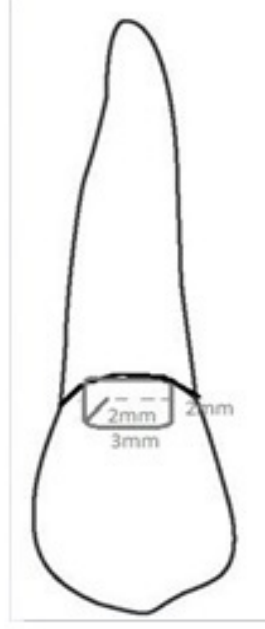

Figure 1. Schematic representation of the cavity configuration
Snap Rainbow Technique Kit, Shofu, Japan) implemented by the same operator. The tested materials and LCUs included in this study have been shown in Table 1 and 2, respectively.

After completion of the restorations, the 3 groups were subdivided according to aging conditions and all samples were stored in distilled water in dark colored glass bottles at room temperature for 24 hours.

\section{Thermal Cycling and Mechanical Loading Procedures}

The test groups subjected to aging procedures underwent thermal cycling (1000 times) between 5 and $55^{\circ} \mathrm{C}$, with a dwell time of 30 seconds at each temperature and a transfer interval of 10 seconds (SD Mechatronic, Germany). Upon completion of these procedures, the samples were subjected to mechanical loading (Dentarge Chewing Simulator, Gaziantep/Turkey) using 50,000 load cycles at a frequency of $1.7 \mathrm{~Hz}$ to replicate an intermittent vertical load of $98 \mathrm{~N}$ on the restorations (14). All samples were submersed in distilled water during the mechanical loading test.

\section{Microleakage Evaluation}

Thereafter, all tooth surfaces (excluding $1 \mathrm{~mm}$ around the restoration margins) were sealed using two layers of nail polish to prevent dye penetration, and the apices were sealed with composite resin. The teeth were then immersed in $0.5 \%$ basic fuchsin dye solution for 24 hours, after which any surface adherent dye was rinsed off under tap water. The teeth were then sectioned longitudinally along the bucco-lingual plane through the center of the restoration using a water cooled, slow speed diamond blade (Esetron Smart Robotechnologies, Ankara/ Turkey) to form two sections. The marginal sealing ability, as indicated by the depth of dye penetration around the enamel and dentinal margins, was evaluated under a stereomicroscope (SMZ1000, NIKON, JAPAN) at 40x magnification. The scoring scale used to assess extent of dye penetration at the tooth-

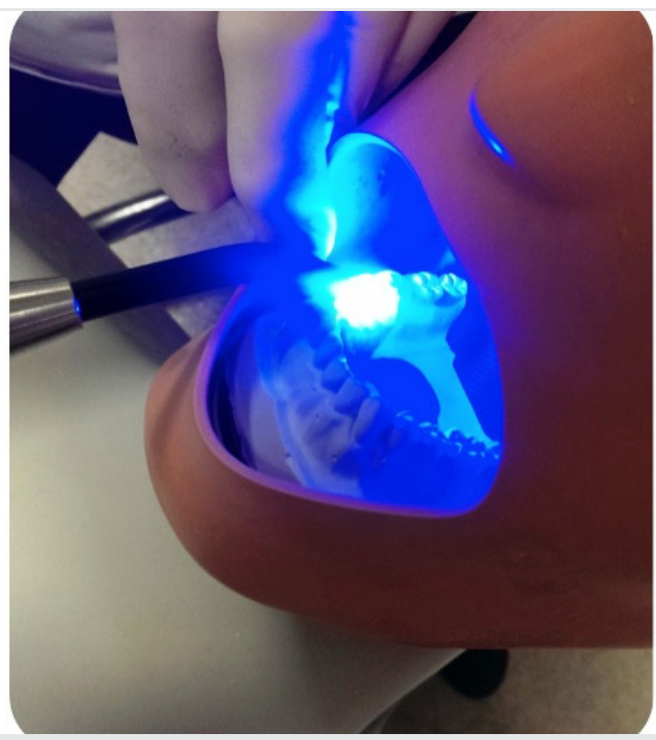

Figure 2. Restorations were performed on a dental phantom head to mimic the oral environment 
restoration interface has been shown below (15), and all visual analyses were performed by two previously calibrated examiners (ND, YSU).

\section{0: No penetration}

1: Infiltration up to the enamel-dentin junction in the occlusal wall or penetration up to $1 / 4$ of the length of the gingival wall.

2: Penetration of the dye up to $1 / 2$ the length of the cavity wall.

3: Penetration of the dye extending to the total depth of the cavity wall.

Microleakage was evaluated in the tested groups after completion of the TMA procedures and in the control groups (which did not undergo TMA procedures) after 24 hours.

\section{Statistical Analyses}

All statistical analyses were performed using SPSS Software for Windows 20.0. As the microleakage values did not exhibit normal distribution, non-parametric tests (Kruskal-Wallis, Mann-Whitney U, and Wilcoxon Signed Ranks tests) were used to carry out pair-wise comparisons among groups. A p value $<0.05$ was considered to be statistically significant.

\section{Results}

Table 3 shows the distribution of the microleakage scores and the results of the statistical analyses. Comparison of the groups showed no significant differences in microleakage scores between the new generation and two conventional LED LCUs used (Table 3).

Upon comparison of the test and control groups polymerized using the new generation LED LCU, a statistically significant difference in microleakage scores was observed along the gingival margins $(p<0.05)$ but not along the occlusal margins $(p>0.05)$.

Comparison of the test and controls groups polymerized using two conventional LED LCUs showed that the former exhibited a higher microleakage score and this difference was statistically significant along the occlusal and gingival margins $(\mathrm{p}<0.001)$ (Figure 3).

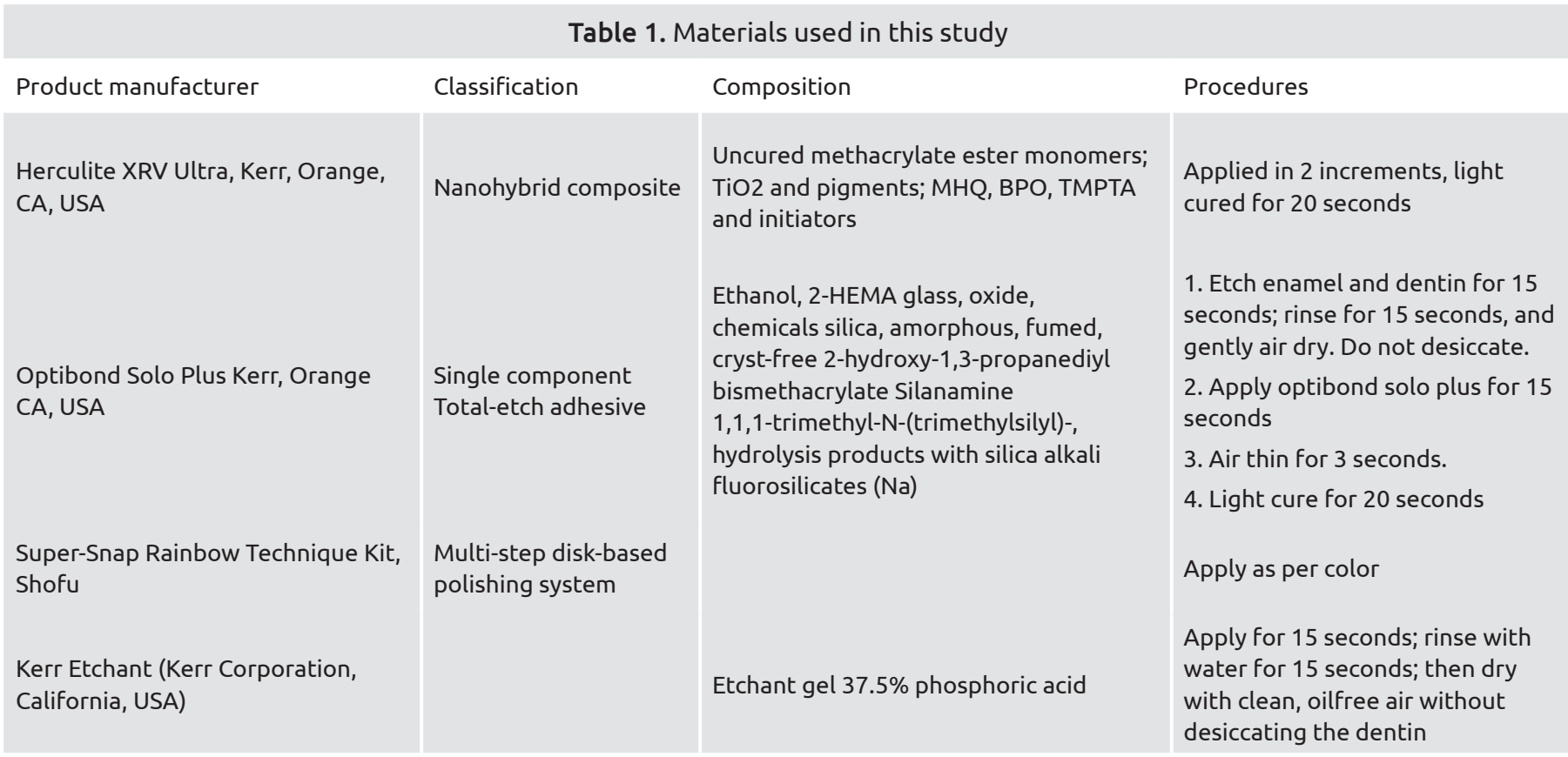

Table 2. Curing units used in this study and their outputs

\begin{tabular}{|l|l|l|l|l|}
\hline Curing unit & Manufacturer & Serial no & Setting & Light intensity mW/cm² \\
\hline High power intensity (LED) & Demi Ultra, Ultracapacitor KERR & 35664 & Standard & 1100 \\
\hline High power intensity (LED) & Optima BA International (UK) & L1340755H & Full power Ramp (soft), Pulse 1200 \\
\hline High intensity (LED) & Valo Cordless, ULTRADENT & C46176 & Standard, high, Xtra & 1000 \\
\hline LED: Light emitting diodes & & & & \\
\hline
\end{tabular}




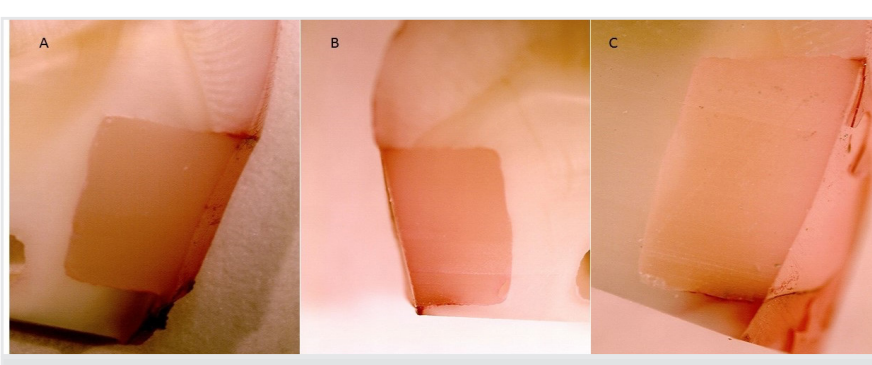

Figure $3(A, B, C)$. Dye penetration on the gingival margin by thermos-mechanical aging groups. A (DEMI): score 2; $\mathrm{B}$ (VALO): score 2; C (OPTIMA): score 3

\section{Discussion}

The current study examined and compared the effects of TMA on the microleakage scores of Class $\mathrm{V}$ composite restorations polymerized using one new generational and two conventional LED LCUs on a phantom simulation device. The findings showed that TMA increased microleakage in Class $\mathrm{V}$ composite restorations, irrespective of the type (new generational or conventional) of LED LCU used. Therefore, the first null hypothesis was accepted and the second was rejected.

Composite resins should be completely polymerized in order to achieve the maximum degree of conversion and highest endurance against occlusal and lateral loads and thermal variations. Previous studies have suggested that LCUs should be held as close as possible to the tooth surface to achieve adequate polymerization (12), with light intensity, composite resin microhardness, and degree of polymerization decreasing as the distance between the light tip and the cavity increases $(16,17)$. Delivery of a sufficient amount of light at the correct wavelength is essential in order to achieve adequate resin polymerization (18), and failure to accomplish this can lead to increased wear, fracture, lesser degree of conversion, and microleakage and subsequent secondary caries (19). Consequently, treatment success is influenced by many factors such as the skill of the operator, type of resin material, application technique, adequate isolation of the cavity, and sufficient light curing (20). The current in vitro study used a dental phantom head to mimic oral conditions, and all prepared human premolar teeth were fixed on a mandibular prototype model made from dental stone.

The distance between the tip of the light curing unit and the tooth is affected by the position of the latter in the dental arch and in relation to the tongue and cheek. Holding the tip of the light curing unit as close to the tooth as possible is a crucial factor affecting polymerization, degree of conversion, microleakage, and the longevity of the restoration (12). According to the ADA (2014) (21) report, increasing the distance between the LCU and the tooth from $2 \mathrm{~mm}$ to $9 \mathrm{~mm}$ decreases the curing depth. Therefore, in the current study, the distance between the light curing unit and the tooth was determined using a standard protocol and all restorations were cured using LCUs held at the same distance.
Other factors that affect resin composite polymerization include the mode, exposure time, type, wavelength, and irradiance (22). In 1999, Chiche (23) reported a lack of an optimal light curing protocol despite the commercial availability of several LCUs with standard, high, ramped or pulsed exposure modes operating over a wide range of spectral radiant power. Harlow et al. (24) used six different LED light sources in their study and found that the radiant energy produced during exposure with ramp mode was not the same as the energy produced when using the standard mode. Additionally, the radiant energy produced with higher power modes over shorter exposure times was also lower than that produced with the standard mode. Devices with high light intensity have several advantages including shorter application time and deeper curing. However, they are also associated with several limitations. Firstly, very rapid polymerization often limits the ability of the composite to flow to the surface of the tooth, thereby transferring polymerization contraction stress from the tooth structure to the bonding surface (25). Secondly, rapid polymerization may also result in the formation of shorter chains with fewer cross-links and lower molecular weight which, in turn, affect the physical properties of the composite resin (13). Therefore, the standard mode of LED LCUs was preferred over the high intensity mode due to the limitations associated with the latter.

As per the manufacturer's instructions, the exposure time for the adhesive system was 10 and 5 seconds with the conventional and new generational LED LCUs, respectively. In contrast, the exposure time for the composite resin was the same for both LED LCUs. Currently, there is a wide range of commercially available LUCs that claim to exhibit superior properties; therefore the aim of this study was to evaluate whether there were any differences in microleakage when using three different LED LCU systems. However, as all the light devices used similar wavelengths and irradiance, no differences in microleakage between the new generational and two conventional LED LCUs were observed, suggesting that the former did not exhibit superior properties as suggested.

Previous studies have suggested that higher energy intensity did not augment the hardness of the composite resin, but rather affected its physical properties (26). Despite controlling the effects of polymerization contraction, marginal microleakage may occur at the adhesive interface of dental restorations, which are subjected to fluctuations in the temperature and $\mathrm{pH}$ of the oral environment, leading to chemical, thermal, and mechanical stresses (27). Thermal stresses may lead to the formation of gaps which, in turn, result in microleakages at the interface caused by a mismatch between the coefficients of thermal expansion between the restorative material and natural tooth structure (28). Since microleakage tests usually assess the sealing ability of restorative materials, previous studies have recommended the use of both thermal and mechanical aging tests to evaluate stress at the adhesive interface in order to mimic in vivo conditions (29). Therefore, the present study utilized thermos-mechanical aging of the restorations to mimic the oral environment and evaluate microleakage scores. Microleakage is often caused by thermal 
cycles or mechanical loading that cause stress and disruptions at the tooth-composite restoration interface due to differences between the restorative material and dental structure $(30,31)$. The current study found that although TMA increased microleakage in all groups, there were no significant differences between the test and control groups when examined by the different types of LCUs used (Figure 3). These findings were consistent with those reported by Soares et al. (13) who examined the effects of thermomechanical load cycling (TMC), polymerization time, and mode on microleakage scores in Class II composite restorations and reported that TMC increased microleakage. Similarly, Erdilek et al. (32) found that microleakage from the gingival margins of two composite resins (Spectrum TPH and Admira Ormocer) significantly increased following cyclic loading $(50,000$ cycles of 50 Newton force).

Upon comparison of the test and controls groups polymerized using new generation LED LCUs, a statistically significant difference in microleakage score was observed at the gingival margin (score 3:11; $\mathrm{p}<0.001$ ) but not at the occlusal margins (score 3:7;p>0.001) (Table 3). However, 7 samples in the current study exhibited a highest score of 3 at the occlusal margin. Conversely, a statistically significant difference $(\mathrm{p}<0.001)$ in microleakage scores was observed at the gingival and occlusal margins when comparing test and control groups polymerized using two conventional LED LCUs (Table 3). The highest microleakage scores were observed in the test groups, with the scores in the gingival margins being higher than that of the occlusal margins. This could be attributed to the effects of TMA. The other reason for the higher microleakage on the gingival margin in the aged group may be due to the ending of the gingival margin on the dentin tissue where the adhesive bonding is more difficult to seal that part of the cavity.

Rapid polymerization of composite resins using high-intensity (Valo cordless) LCUs often leads to polymerization contraction, as suggested by Yoshikawa et al. (33) who compared low and high-intensity LCUs and found that the latter yielded inadequate polymerization of the resin composite and poor adaptation to the cavity wall, causing marginal gap formation.

Nalçacı et al. (34) reported that the performance of resin composite restorations was affected by the polymerization light sources and modes used. Similarly, Yilmaz et al. (35) compared microleakage in resin composites polymerized with QTH and two types of LED LCUs and found that microleakage could be minimized by polymerizing with high-density output LEDs. They also stated that microleakage was affected by the type of light curing unit used.

\section{Study Limitations}

The limitation of this study can be the thermomechanical aging that was applied to the specimens corresponding to 1 month. It may be better to apply thermomechanical aging procedure which equals to 1 year.

\section{Conclusion}

Within the limitations of the study, it may be concluded that thermal and mechanical aging procedures increase the microleakage in Class V composite restorations regardless of the type of light curing unit used.

\section{Ethics}

Ethics Committee Approval: This study was approved by Bezmialem Vakif University Ethics Committee (No: 04.04.20177/54).

Informed Consent: In vitro study.

Peer-review: Externally peer reviewed.

\section{Authorship Contributions}

Design: Y.Ş.U., Data Collection or Processing: A.U., Analysis or Interpretation: Ş.H.S., Writing: N.D.

Conflict of Interest: No conflict of interest was declared by the authors.

Financial Disclosure: The authors declared that this study received no financial support.

\section{References}

1. Gladwin M, Bagby M. "Clinical aspects of dental materials. Theory, practice, and cases”. 3rd ed. China: Lippincott Williams \&Wilkins, 2009.p.55-73. http://thuvienso.vanlanguni.edu.vn/handle/Vanlang $\mathrm{TV} / 13592$

2. de Camargo EJ, Moreschi E, Baseggio W, Cury JA, Pascotto RC. Composite depth of cure using four polymerization techniques. J Appl Oral Sci 2009; 17:446-50.

3. Ceballos L, Fuentes MV, Tafalla H, Martinez A, Flores J, Rodriguez J. Curing effectiveness of resin composites at different exposure times using LED and halogen units. Med Oral Patol Oral Cir Bucal 2009;14:E51-6.

4. Rueggeberg FA, Giannini M, Arrais CAG, Price RBT. Light curing in dentistry and clinical implications: a literature review. Braz Oral Res 2017;31(suppl 1):e61.

5. Jandt KD, Mills RW. A brief history of LED photopolymerization. Dent Mater 2013;29:605-17.

6. Cayless MA, Marsden AM. "Tungsten halogen lamps. In: Lamps and lighting”. 3rd ed. London: Edward Arnold Ltd, 1983.p.169-82.

7. Ernst CP, Schattenberg A, Stender E, Willershausen B. Relative Oberfl"achenh" arte verschiedener Komposite nach LEDPolymerisation aus $7 \mathrm{~mm}$ Abstand. [Relative surface hardness of various composites after LED polymerization from $7 \mathrm{~mm}$ distance.] Dtsch Zahn“" arztl Z 2005;60:154-60.

8. Vandewalle KS, Roberts HW, Andrus JL, Dunn WJ. Effect of light dispersion of LED curing lights on resin composite polymerization. J Esthet Restor Dent 2005;17:244-54; discussion 254-5.

9. Soh MS, Yap AU, Siow KS. The effectiveness of cure of LED and halogen curing lights at varying cavity depths. Oper Dent 2003;28:707-15. 
10. Rawls HR, Esquivel-Upshaw JF. "Restorative resins". In: Anusavice KJ, editor. Phillip's Science of dental materials. 11th ed. St.Louis MO:Mosby; 2003.p.399-442.

11. Demi ultra LED ultracapacitor-curing-light-system [Internet]. Available from: URL: https://www.kerrdental.com/kerr-restoratives/ demi-ultra-led-ultracapacitor-curing-light-system. https://www. kerrdental.com/kerr-restoratives/demi-ultra-led-ultracapacitorcuring-light-system

12. Price RB, Labrie D, Whalen JM, Felix CM. Effect of distance on irradiance and beam homogeneity from 4 light-emitting diode curing units. J Can Dent Assoc 2011;77:b9.

13. Soares GP, Ambrosano GM, Lima DA, Marchi GM, CorrerSobrinho L, Lovadino JR, et al. Effect of light polymerization time, mode, and thermal and mechanical load cycling on microleakage in resin composite restorations. Lasers Med Sci 2014;29:545-50.

14. Jung SH, Min KS, Chang HS, Park SD, Kwon SN, Bae JM. Microleakage and fracture patterns of teeth restored with different posts under dynamic loading. J Prosthet Dent 2007:98:270-6.

15. Shahabi S, Ebrahimpour, Walsh LJ. Microleakage of composite resin restorations in cervical cavities prepared by Er,Cr:YSGG laser radiation. Aust Dent J 2008;53:172-5.

16. Lindberg A, Peutzfeldt A, van Dijken JW. Effect of power density of curing unit, exposure duration, and light guide distance on composite depth of cure. Clin Oral Investig 2005;9:71-6.

17. Schattenberg A, Lichtenberg D, Stender E, Willershausen B, Ernst CP. Minimal exposure time of different LED-curing devices. Dent Mater 2008;24:1043-9.

18. Roberts HW, Vandewalle KS, Berzins DW, Charlton DG. Accuracy of LED and halogen radiometers using different light sources. J Esthet Restor Dent 2006;18:214-24.

19. Vandewalle KS, Ferracane JL, Hilton TJ, Erickson RL, Sakaguchi RL. Effect of energy density on properties and marginal integrity of posterior resin composite restorations. Dent Mater 2004;20:96-106.

20. Price RB. Light energy matters. J Can Dent Assoc 2010;76:a63.

21. ADA Professional Product Review. A publication of the council on scientific affairs. In: David C, editor, Sarret JADA 2014;145:1164-6.

22. Caughman WF, Rueggeberg FA, Curtis JW Jr. Clinical guidelines for photocuring restorative resins. J Am Dent Assoc 1995;126:1280-2, 1284,1286 .
23. Chiche GJ. The search for a standard light-curing protocol. Pract Periodontics Aesthet Dent 1999;11:260.

24. Harlow JE, Sullivan B, Shortall AC, Labrie D, Price RB. Characterizing the output settings of dental curing lights. J Dent 2016;44:20-6.

25. Asmussen E, Peutzfeldt A. Polymerization contraction of resin composite vs. energy and power density of light-cure. Eur J Oral Sci 2005;113:417-21.

26. Pires JA, Cvitko E, Denehy GE, Swift EJ Jr. Effects of curing tip distance on light intensity and composite resin microhardness. Quintessence Int 1993;24:517-21.

27. Geis-Gerstorfer J. In-vitro corrosion measurements of dental alloys. J Dent 1994;22:247-51.

28. Versluis A, Douglas WH, Sakaguchi RL. Thermal expansion coefficient of dental composites measured with strain gauges. Dent Mater 1996;12:290-4.

29. Leibrock A, Degenhart M, Behr M, Rosentritt M, Handel G. In vitro study of the effect of thermo and load-cycling on the bond strength of porcelain repair systems. J Oral Rehabil 1999;26:130-7.

30. Mitsui FH, Peris AR, Cavalcanti AN, Marchi GM, Pimenta LA. Influence of thermal and mechanical load cycling on microtensile bond strengths of total and self-etching adhesive systems. Oper Dent 2006;31:240-7.

31. Cavalcanti AN, Mitsui FH, Silva F, Peris AR, Bedran-Russo A, Marchi GM. Effect of cyclic loading on the bond strength of class II restorations with different composite materials. Op Dent 2008;33:163-8.

32. Erdilek D, Dörter C, Koray F, Kunzelmann KH, Efes BG, Gomec Y. Effect of Thermo-mechanical load cycling on microleakage in class II ormocer restorations. Eur J Dent 2009;3:200-5.

33. Yoshikawa T, Burrow MF, Tagami JA. Light curing method for improving marginal sealing and cavity wall adaptation of resin composite restorations. Dent Mater 2001;17:359-66.

34. Nalçacı A, Salbafl M, Ulusoy N. The effects of soft start vs continuous - light polymerization on microleakage in class II resin composite restorations. J Adhes Dent 2005;7:309-14.

35. Yilmaz F, Gonulol N, Guler E, Ersoz E, Aytac F. Effects of different light sources on microleakage of composite resins with different monomer structures. J Dent Sci 2014;9:364-70. 